\title{
Isolated Bladder Condyloma in an Immunocompetent Female: Case Report and Literature Review
}

\author{
İmmünokompetan Bir Kadında Izole Mesane Kondilomları: Olgu Sunumu ve Literatür \\ Incelemesi
}

\author{
(1) Nancy Wang ${ }^{1}$, (1) Michael Deftos², (1) Jeffrey Reese ${ }^{3}$ \\ 1Stanford Hospital, Clinic of Urology, Stanford, USA \\ 2Santa Clara Valley Medical Center, Clinic of Pathology, San Jose, USA \\ ${ }^{3}$ Santa Clara Valley Medical Center, Clinic of Urology, San Jose, USA
}

\begin{abstract}
Condyloma acuminata (CA), lesions caused by strains of the human papilloma virus, are usually limited to anogenital and mucocutaneous regions. Though uncommon, isolated urinary CA lesions have been seen in some immunocompromised patients. We report a rare case of an immunocompetent 37-year-old female with innumerable bladder condylomas.
\end{abstract}

Keywords: Condyloma acuminata, Bladder, Human papilloma virus, Immunocompetent

Öz

İnsan papilloma virüsü suşlarının neden olduğu kondiloma aküminata (CA) lezyonları, genellikle anogenital ve mukokutanöz bölgelerle sınırlıdır. Bağışıklık sistemi baskılanmış bazı hastalarda nadir de olsa izole üriner CA lezyonları görülmüştür. Bu çalışmada, sayısız mesane kondilomlu ve immünokompetan olan 37 yaşında bir kadına ait nadir bir olgu sunulmuştur.

Anahtar Kelimeler: Kondiloma akuminata, Mesane, İnsan papilloma virüsü, İmmünokompetan

\section{Introduction}

There are over 200 strains in the human papilloma virus (HPV) family, but there are four predominant infectious strains associated with symptoms and carcinomas: HPV 6 and HPV 11 cause approximately 90\% of all genital warts, HPV 16 and HPV 18 are associated with anogenital carcinomas (1). Condyloma acuminata (CA), the warty lesions caused by HPV, are generally present on external genitalia and mucocutaneous junctions and can spread locally. There are rare reports of CA found in the urinary tract, but these are generally seen in patients who are immunocompromised and who have had a history of genital CA (2). While genital condylomas have been associated with increased risk of cervical, anogenital, penile, and head and neck cancers, their role in urothelial carcinoma has been very inconclusive, (3) with some reports suggesting an increased risk for progression to squamous cell carcinoma and need for close monitoring (4). We report a rare case of isolated bladder CA found in an immunocompetent female without a history of genital CA.

\section{Case Presentation}

The patient is a 37-year-old female with a history of kidney stones who presented with left flank pain and gross hematuria. Computed tomography scan of the abdomen and pelvis showed multiple small stones in her left kidney. Given the small size and location, she was managed conservatively. However, she continued to have flank pain on follow-up and decided to pursue elective ureteroscopy and laser lithotripsy for stone treatment.

Correspondence: Nancy Wang MD, Stanford Hospital, Clinic of Urology, Stanford, USA

Phone:+6507233391_E-mail: nwang4@stanford.edu ORCID-ID: orcid.org/0000-0003-0796-5625

Received: $30.10 .2017 \quad$ Accepted: 27.12.2017

Cite this article as: Wang N, Deftos M, Reese J. Isolated Bladder Condyloma in an Immunocompetent Female: Case Report and Literature Review. J Urol Surg 2019;6(1):68-70.

oCopyright 2019 by the Association of Urological Surgery / Journal of Urological Surgery published by Galenos Publishing House. 
Standard cystoscopy was performed at the start of the case which revealed numerous bladder lesions that appeared papillary along with some lesions of abnormal mucosa concerning for carcinoma in situ. The largest lesion measured approximately $1 \times 2 \mathrm{~cm}$ in the right posterior wall, but smaller lesions were seen throughout the bladder including the dome, lateral walls and trigone.

Given this finding and concern for urothelial carcinoma, we determined that it was in the patient's best interest to proceed with transurethral resection of bladder tumor with cold cup biopsies and to abort the ureteroscopy so as not to expose the upper tracts to possible carcinoma. The patient was informed of the findings after the procedure.

The bladder biopsy pathology came back as fibrovascular cores consistent with underlying papillary growth but no carcinoma. Immunohistochemical staining was positive for $\mathrm{p} 40$ and elevated ki-67 but negative for GATA3, p16 and CK20. The differential diagnosis was for condyloma acuminatum versus urothelial hyperplasia and the pathology was sent to Stanford University for consultation read. A review of the patient's previous surgical pathology showed that she had a similar bladder mass resected in 2012, which was read as urothelial hyperplasia. This specimen was also sent along to for re-analysis.

The Stanford pathology read determined that both the 2012 and current bladder tissue samples were consistent with condyloma acuminatum. The haemotoxylin and eosin staining showed nonkeratinizing squamous mucosa with koilocytic and papillomatous changes consistent with CA (Figure 1). Both tissue samples were then sent to the Mayo Clinic Laboratories in Rochester for HPV typing. Commercial typing is available for six strains: $\operatorname{HPV} 8,11,16,18,33$ and 51 , and both samples were negative for all six.

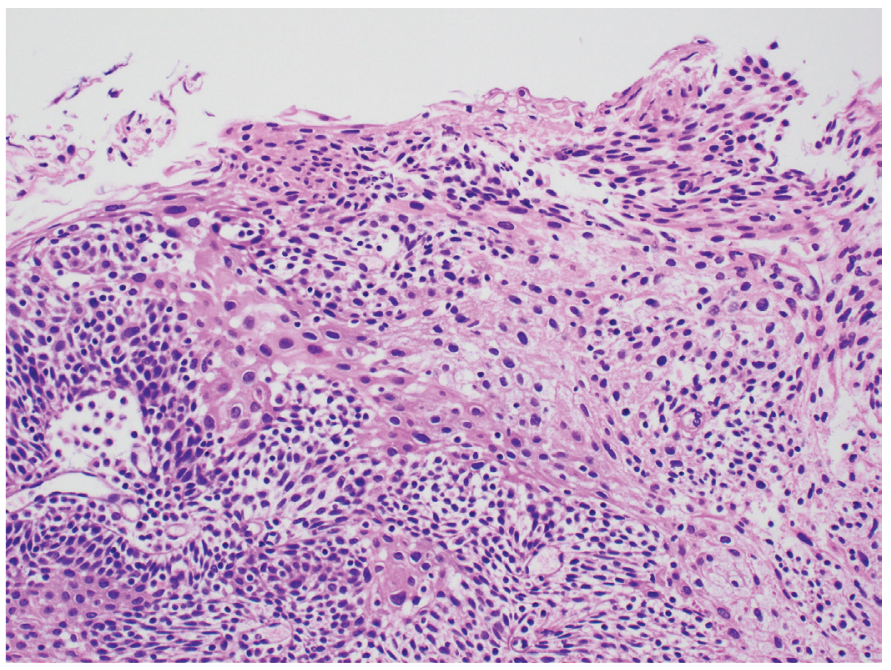

Figure 1. Biopsy histology at 200x magnification showing well-developed koilocytic change characteristic of human papilloma virus-effect with enlarged, hyperchromatic nuclei and perinuclear clearing
On her post-operative visit, the patient was evaluated for any signs of immunocompromise. She denied any history of HPV sexually transmitted infections or genital condylomas. She had not had any abnormal pap smears or irregularities reported on gynecologic exam. Labs for hepatitis B, hepatitis C, gonorrhea, chlamydia and human immunodeficiency virus (HIV) were all negative. The patient was then seen back in the clinic 3 months after the procedure for follow-up cystoscopy, which was negative for any signs of recurrence.

Written informed consent was obtained from the patient.

\section{Discussion}

A review of current English literature conducted through PubMed yielded 44 articles with a total of 52 cases of CA reported in the bladder. Of these cases, $16(31 \%)$ had a history of or concurrent anogenital condylomas, $14(27 \%)$ had concurrent urethral and ureter involvement, $19(36 \%)$ had isolated bladder condylomas and $3(6 \%)$ studies had only abbreviated abstracts available. The male-to-female ratio in our review was 1:1.6, which is consistent with the literature.

Urinary involvement is theorized to be secondary to local invasion, which may explain the higher rate of incidence in women given their shorter urethral length (5). However, in patients without a history of genital CA and are otherwise asymptomatic, it has been suggested that isolated bladder or ureteral involvement may be due to iatrogenic urogenital inoculation with urethral procedures and catheterization (6).

Isolated involvement of the bladder continues to be very rare with only 19 cases reported in the English literature. The majority of these patients had some form of immunocompromise including a recent history of renal transplant $(7,8,9,10)$, HIVpositive status $(11,12)$ chronic lymphocytic leukemia $(13)$ and multiple sclerosis (14). Indeed, immunodeficiency has been cited as a risk factor for the development of symptomatic HPV infection in general, as studies of HPV cervical infections show that the large majority of female patients with appropriate T-cell immune responses are able to clear the infection, even when they are infected with high-risk strains (15). Of the 19 cases of isolated bladder lesions, only 7 cases (13\%) occurred in immunocompetent patients.

Of these cases, only 8 cases had positive identification of the HPV strain involved: HPV 6/11 was identified in 5 cases $(6,13,16)$, HPV 16/18 in one case (4), and two cases simply reported immunohistochemistry-positive for HPV without specifying the strain $(8,12)$. Several cases reported negative results of HPV testing, similar to our case, which is likely a reflection of testing limitations as there are over 40 transmissible strains of HPV and commercial testing is limit to the most common HPV strains. 
HPV is a well-known risk factor for the development and progression of certain types of cervical, anal, anogenital, and nasopharyngeal cancers, especially in immunocompromised states. However, our study and a review of the literature show that even immunocompetent patients are at risk of developing isolated urinary CA. Although the relationship between HPV and urothelial carcinomas is controversial, close monitoring with routine cystoscopy is strongly recommended for these patients.

\section{Acknowledgments}

We would like to acknowledge the work and contributions of the Stanford Pathology Department as well as the Mayo Clinic Medical Laboratories in Rochester. The authors do not have any conflicts of interest to disclose.

\section{Ethics}

Informed Consent: Written informed consent was obtained from the patient.

Peer-review: Internally peer-reviewed.

\section{Authorship Contributions}

Surgical and Medical Practices: N.W., M.D., J.R., Concept: J.R., Design: N.W., J.R., Data Collection or Processing: N.W., M.D., J.R., Analysis or Interpretation: N.W., M.D., J.R., Literature Search: N.W., Writing: N.W.

Conflict of Interest: No conflict of interest was declared by the authors.

Financial Disclosure: The authors declared that this study received no financial support.

\section{References}

1. National Cancer Institute. HPV and Cancer. https://www.cancer.gov/aboutcancer/causes-prevention/risk/infectious-agents/hpv-fact-sheet

2. Mistro AD, Koss LG, Bruanstein J, Bennett B, Saccomano G, Simons KM. Condylomata acuminate of the urinary bladder. Natrual history, viral typing, and DNA content. Am J of Surg Path 1988;12:205-215.
3. Guma S, Maglantay R, Lau R, Wieczorek R, Melamed J, Deng FM, Zhou M, Makarov D, Lee P, Pincus MR, Pei ZH. Papillary urothelial carcinoma with squamous differentiation in association with human papilloma virus: case report and literature review. Am J Clin Exp Urol 2016;4:12-16.

4. Chrisofos $M$, Skolarikos $A$, Lazaris $A$, Bogris $S$, Deliveliotis Ch. HPV 16/18-associated condyloma acuminatum of the urinary bladder: first international report and review of literature. Int J STD AIDS 2004;15:836828.

5. Jeje EA, Ogunjimi MA, Alabi TO, Awolola NA, Ojewola RW. Condyloma acuminate of the bladder in benign prostatic obstruction: case report and review of literature. Niger Postgrad Med J 2015;22:189-193.

6. Iwasawa A, Kumamoto $Y$, Maruta $H$, Fukushima M, Tsukamoto T, Fujinaga $K$, Fujisawa $Y$, Kodama N. Presence of human papillomavirus 6/11 DNA in condyloma acuminatum of the urinary bladder. Urol Int 1992;48:235-238.

7. Nambirajan A, Shukla AK, Mathur SR, Kumar H, Kumar R, Bhowmik DM, Singh A, Jain D, Sharma MC, Kaushal S. Condyloma Acuminatum of Urinary Bladder in a Male Renal Transplant Recipient - A Diagnostic and Therapeutic Challenge. Clin Genitourin Cancer 2017;15:739-742.

8. Guo CC, Fine SW, Epstein JI. Noninvasive squamous lesions in the urinary bladder: a clinicopathologic analysis of 29 cases. Am J Surg Pathol 2006;30:883-891.

9. Nielsen HV. Condylomata acuminate of the bladder. Scan J Urol Nephrol 1975;9:169-170

10. Pettersson S, Hansson G, Blohme I. Condyloma acuminatum of the bladder. J Urol 1976;115:535-536.

11. Lazarus J, Kaestner L. Intravesical condylomata accuminata in HIV positive patient. Can J Urol 2011;18:5663-5665.

12. Jimenez Lasanta JA, Mariscal A, Tenesa M, Casas D, Gallart A, Olazabal A. Condyloma acuminatum of the bladder in a patient with AIDS: radiological findings. J Clin Ultrasound 1997;25:338-340.

13. Del Mistro A, Koss LG, Braunstein J, Bennett B, Saccomano G, Simons KM. Condylomata acuminate of the urinary bladder. Natural history, viral typing, and DNA content. Am J Surg Pathol 1988;12:205-215.

14. Van Poppel H, Stessens R, de Vos R, van Damme B. Isolated condyloma acuminatum of the bladder in a patient with multiple sclerosis: etiological and pathological considerations. J urol 1986;136:1071-1073.

15. Stanley M. Pathology and epidemiology of HPV infection in females. Gynecol Oncol 2010;117;(Suppl 2):5-10.

16. Botella E, Burgues O, Navarro S, Ramos D, Ferrer J, Gimeno C, LlombartBosch A. Warty carcinoma arising in condyloma acuminatum of urinary bladder: a case report. Int J Surg Pathol 2000;8:253-259. 